\title{
SCALE-UP Implementation and Intra-Institutional Dissemination: A Case Study of Two Institutions
}

\author{
Kathleen T. Foote ${ }^{1}$, Xaver Neumeyer ${ }^{2}$, Charles Henderson ${ }^{2}$, Melissa Dancy ${ }^{3}$, \\ Robert Beichner ${ }^{1}$
}

\author{
${ }^{1}$ Department of Physics, North Carolina State University, 421 Riddick Hall, Raleigh, NC 27695-8202 \\ ${ }^{2}$ Department of Physics, Western Michigan University, 1903 West Michigan Ave, Kalamazoo, Michigan 49008 \\ ${ }^{3}$ Department of Physics, University of Colorado at Boulder, 390 UCB, Boulder, CO 80309-0390
}

\begin{abstract}
Much time, money and effort has been spent developing innovative teaching methods that have been shown to improve student learning in college classes. Although these have had some influence on mainstream teaching, many have failed to bring about widespread transformation. This exploratory case study examines the intra-institutional diffusion of the SCALE-UP (Student-Centered Active Learning Environment with Upside-Down Pedagogies) reform [1]. We interviewed key contact people at two, large, public institutions where SCALE-UP has spread in multiple departments. Our preliminary findings indicate that broad adoption is facilitated by faculty-administrative partnership, interdisciplinary reform efforts and redesigned classrooms that raise visibility.
\end{abstract}

Keywords: educational reform, dissemination, SCALE-UP, studio classroom, active learning, flipped classroom

PACS: 01.40.Fk, 01.40.gb, 01.78.+p

\section{INTRODUCTION}

There have been many calls for improving college teaching [2]. Much time, money and effort has been put into developing innovative teaching methods and curriculum, documenting their effectiveness, and disseminating results. While these efforts, largely based in the Development and Dissemination model of change, have had some influence on mainstream teaching, they have failed to bring about widespread and sustained transformation [3]. We seek to develop a more impactful change model by examining the mechanisms for inter- and intra-institutional dissemination.

This paper examines the spread of research-based innovations through case studies of two secondary implementations of the SCALE-UP instructional innovation. The goal of the case studies is deepen our research-based understanding of change and to contribute to a more robust implementation model.

\section{PARTICIPANTS AND DATA COLLECTION}

We selected two universities for this study based on 812 web survey responses from people registered on the SCALE-UP website [4]. From the 314 institutions represented in the survey, the two institutions were selected based on criteria such as: i) longevity of implementation, ii) number of departments involved, and iii) geographical location.

\section{A. SCALE-UP}

SCALE-UP is a popular studio-based instructional innovation that can be described by expanding its acronym: Student-Centered Active Learning Environment with Upside-down Pedagogies. Carefully designed rooms and furnishings facilitate the use of instructional modes like the "flipped classroom," collaborative learning, problem-based instruction, and guided inquiry [1].

Robert Beichner at North Carolina State University (NCSU) developed SCALE-UP in the mid-1990s to facilitate group-oriented learning in large enrollment physics courses. Now SCALE-UP is used in classes of varying sizes, in dozens of disciplines, all around the world [5]. We chose to examine SCALE-UP because it has spread through a variety of formal and informal channels, has crossed disciplines, radically departs from traditional instruction, and has been implemented in a variety of ways at numerous secondary sites.

\section{B. The Two Institutions}

The University of Iowa (UI) is a public research university with an enrollment of about 31,000 students in Iowa City, IA. Clemson University is a public landand sea- grant research institution in Clemson, $\mathrm{SC}$ with 
an enrollment of 21,000 students. UI and Clemson University present different paths of inter-institutional dissemination. Upper administration brought SCALEUP-style instruction (which they call TILE: "Transform, Interact, Learn, Engage") to UI in 2009 as a top-down initiative. At Clemson, two faculty members (one from math and one from engineering) worked bottom-up to bring SCALE-UP to campus.

\section{Data Collection}

From the web survey, we identified key spokespeople in each university to target for further information, conducting detailed interviews with four people involved with the reform effort at each university. At UI, we interviewed an administrator and three professors (sociology, biology and earth/environmental science). At Clemson, we interviewed four faculty members: two from mathematics and two from engineering, one of whom no longer works there.

Each semi-structured interview lasted approximately one hour and contained open-ended questions about the interviewee's history with reform efforts, the process of implementation and the institutional/departmental culture. For example, questions included: (a) Describe your personal experiences with SCALE-UP, (b) what role does SCALE-UP currently play in your department, (c) how do instructors implement SCALE-UP in your department? The interviewer used follow-up questions to obtain specific details about the interviewee's experiences. Each interview was transcribed for analysis.

\section{Data Analysis}

Individual interviews were reviewed and summarized. Then, interviews at the same institution were compared to ensure stories were consistent and to highlight thematic findings. Finally, interviews were compared to those from the other institution to identify important similarities and differences in the process. Interview responses were supplemented by published literature and institutional websites.

\section{PRELIMINARY FINDINGS}

\section{A. Initiation}

In 2009, three events coincided at UI: a major flood resulted in the need to reconstruct many classrooms, a significant amount of federal funding was available [5] and a video of the "Active Learning Classrooms" at the University of Minnesota (UMN) was circulating around campus, creating excitement about technologyrich classrooms. When the Provost created a Learning Spaces Executive Team to decide how to use the stimulus funding to improve their campus, they chose to reconstruct two classrooms in a technology-rich, studio-style. Although the decision to implement TILE came as a top-down initiative from administration, the TILE developers purposefully reached out to faculty for input designing the classrooms.

At Clemson, two faculty members (one in mathematics and one in engineering) had already been working together and thinking about reformed pedagogies as part of the SUCCEED project (one of the National Science Foundation's engineering education coalitions). This preliminary exposure to SCALE-UP was rekindled at a conference in 2001 by a conversation with one of Beichner's graduate students. The engineering professor worked with the director of engineering education to successfully petition the Provost for funds to renovate a classroom, under the expectation that further funding would be sought from external sources. The math professor secured a classroom in 2006 by petitioning his department head, who was open to innovative pedagogies and wanted to reduce failure rates.

\section{B. Implementation}

UI based their classroom design on the NCSU and UMN models, equipped with projection capabilities, round tables, shared computers and whiteboards on walls. UI began with 2 TILE classrooms, which any department could use through a centrally controlled scheduling system.

Although other implementations inspired the classroom design, UI developed their own professional development program to accompany the reformed space [6]. To ensure instructors made proper use of the redesigned classrooms, the Center for Teaching and Instructional Services created a mandatory training program for interested faculty to learn theories of active and technology-based learning and see demonstrations from current users. Some department heads encouraged faculty to get involved by encouraging younger colleagues to attend training and sometimes participated themselves.

At Clemson, SCALE-UP classrooms were developed and controlled by departments. The first SCALE-UP classroom also closely followed the NCSU model. The department head asked the engineering professor to redesign the first year curriculum and allowed him to adopt a SCALE-UP format. The professor used a blended pedagogy of his own engineering education research, using Matlab and computer-based demonstrations, with findings from active and collaborative learning. 


\begin{tabular}{|c|c|c|}
\hline & University of Iowa & Clemson University \\
\hline $\begin{array}{r}\text { Implementation } \\
\text { Initiation } \\
\end{array}$ & - $\quad$ Top-down from upper administration & $\begin{array}{l}\text { - Bottom-up from two faculty members (one in math } \\
\text { and one in engineering) }\end{array}$ \\
\hline $\begin{array}{r}\text { First } \\
\text { Exposure }\end{array}$ & $\begin{array}{l}\text { - Classroom visit by Chief Information Officer to } \\
\text { the University of Minnesota } \\
\text { - Videos of Minnesota's classrooms circulated } \\
\text { around campus }\end{array}$ & $\begin{array}{l}\text { - Faculty heard about SCALE-UP through } \\
\text { participation in the engineering reform grant } \\
\text { - A conversation with Beichner's graduate student } \\
\text { revived this interest in } 2001\end{array}$ \\
\hline $\begin{array}{r}\text { External } \\
\text { Influences }\end{array}$ & $\begin{array}{l}\text { - A major flood resulted in the need to reconstruct } \\
\text { many classrooms } \\
\text { - Federal funding was available }\end{array}$ & $\begin{array}{l}\text { - High failure rates in gatekeeper courses in math and } \\
\text { engineering prepared administrators for change }\end{array}$ \\
\hline $\begin{array}{r}\text { First } \\
\text { Classrooms } \\
\end{array}$ & $\begin{array}{l}\text { - Began with } 2 \text { classrooms in } 2009 \text { (seating } 54 \text { and } \\
\text { 81), design followed UMN/NCSU models }\end{array}$ & $\begin{array}{l}\text { - Began with } 2 \text { classrooms in } 2004 \text { (seating } 26 \text { and } \\
72 \text { ), design followed NCSU model }\end{array}$ \\
\hline $\begin{array}{r}\text { Continued } \\
\text { Spread }\end{array}$ & $\begin{array}{l}\text { - The Center for Teaching and instructional } \\
\text { services ran a mandatory training program } \\
\text { before instructors could use rooms } \\
\text { - } \quad \text { Room assignments were centrally controlled } \\
\text { - Some departments offered incentives for their } \\
\text { faculty to apply, faculty and student enthusiasm } \\
\text { motivated other faculty to apply }\end{array}$ & $\begin{array}{l}\text { - In 2006, math department head decided all } \\
\text { introductory calculus courses would be SCALE-UP } \\
\text { - Spread from math and general engineering to civil } \\
\text { and mechanical engineering because of an } \\
\text { interdisciplinary grant } \\
\text { - Current instructors invited visitors to observe classes } \\
\text { to spread the reform outside STEM }\end{array}$ \\
\hline $\begin{array}{r}\text { Current } \\
\text { Status } \\
\end{array}$ & $\begin{array}{l}\text { - } 7 \text { TILE classrooms and one TILE flex } \\
\text { classroom, used by } 60 \text { departments }\end{array}$ & - 10 SCALE-UP classrooms, used by 10 departments \\
\hline
\end{tabular}

In mathematics at Clemson, the original champion decided to trial the reform in his multivariate calculus course for engineers by switching from traditional instruction to SCALE-UP mid-semester. His students almost unanimously preferred the latter and it allowed him to incorporate Maple tutorials, in-class team-based learning and team projects [7]. Inspired by this course's success and under pressure to reduce high failure rates, the math department head decided to convert all introductory classes to a SCALE-UP format later that year, transforming 5 out of the 6 math classrooms to SCALE-UP spaces. Before the semester started, the math champion helped run a one-day training workshop and the department ran subsequent professional development informally through interdepartmental mentoring.

\section{Current Status}

UI's TILE program continues to grow, especially as the program's first batches of students and instructors discussed their experiences around campus. From 2010 to 2013, TILE trained 214 staff who taught 542

course sections, with a total enrollment of 10898 students [5].

At Clemson, SCALE-UP continued to spread when these two faculty champions joined faculty from civil and mechanical engineering on an NSF grant. Federal funding and this interdisciplinary effort allowed the number of classrooms and course offerings to grow. Civil engineering reformed their statics course to SCALE-UP, in an effort to cut high failure rates.
Mechanical engineering developed a 5-credit integrated statics and dynamics course to replace a pair of traditionally taught courses, an integration that would not have been possible without the flexibility of a SCALE-UP format. All general engineering courses switched to a SCALE-UP format. Since general engineering tends to recruit teaching-focused faculty and involved all instructors in the reform process, this change met little resistance.

In mathematical sciences, the mandate to teach with SCALE-UP was less well received by faculty who lacked familiarity with these teaching methods and skeptical of educational research. When the department head that facilitated the SCALE-UP-conversion retired and instructors regained more autonomy in teaching, some professors reverted toward more traditional methods.

Currently, Clemson has at least 10 SCALE-UP classrooms (and plan to build more). SCALE-UP instructors have invited alumni and colleagues from other departments to observe classes, which has increased visibility and support on campus.

\section{RESULTS}

Since the idea to implement SCALE-UP style instruction came from different directions, comparing these two case studies highlights some important themes. The following factors appear to be important contributors to the implementation effort at both institutions. We present them here as hypotheses for successful institution-level SCALE-UP implementation. 
1) Administration-faculty partnerships facilitate the adoption of SCALE-UP. Since SCALE-UP requires scheduling changes and a redesigned room, a successful implementation effort is difficult without the support of higher administration. At UI, the switch to technology-infused rooms started as a top-down effort from the Provost but the administration purposefully involved faculty members in classroom design. UI consciously balanced "the top-down control of the initiative that characterized the project's beginning and the bottom-up buy-in that would be necessary if the project were to be a success" [5, pp. 172]. Consulting faculty successfully gave instructors a feeling of ownership that increased their interest and investment in these spaces.

SCALE-UP was implemented at Clemson because two motivated faculty champions were enthusiastic about change and appealed to higher administration. Fortunately, department heads in both engineering and mathematics provided the support they needed to build classrooms until federal funding could be secured. Both of these administrators appreciated educational reforms and were especially willing to try something new to reduce high failure rates in gatekeeper courses.

Both institutions initially needed financial support and approval from administrators to build classrooms and start the reform effort while positive feedback from faculty and students helped the reform to spread and become self-sustaining.

2) Redesigned classrooms add visibility and gain support for the reform. An instructor typically cannot make significant changes to the classroom space without consulting the department head and/or administrators. These conversations about SCALE-UP helped spread awareness, create excitement and find support.

Although the financial investment required to renovate classroom space may initially challenge the reform effort, once built, the classrooms stand as a physical symbol of change. Both institutions used these classrooms in creative ways to publicize the reform. At UI, the renovated spaces motivated faculty members to apply to training to earn the privilege of using these spaces. At Clemson, instructors using SCALE-UP invited colleagues from different departments and alumni to observe classes in session. This increased awareness about how SCALE-UP works and inspired the outside community to contribute monetary support.

Finally, we hypothesize the financial investment in the classroom may make it less likely for sites to abandon their use. For example, after the department head in mathematics retired, even though some instructors reverted to more traditional techniques, many retained elements of a more interactive pedagogy since they still taught in reformed spaces.
Both of these universities demonstrate that the physical structure of reformed classroom help sustain and further disseminate the reform.

\section{DISCUSSION}

Although our case study examined SCALE-UP, our results have implications for dissemination of any intra-institutional reform. Even if collaborating with administrators is not required for implementation, starting these conversations could alert campus of a reform effort and help gain momentum [3]. Administrative support may provide this added accountability to encourage individuals to persevere with the implementation effort.

Even if a reform does not require a studio-style classroom, reforms may benefit from some physical symbol of change. Having this tangible indication of reform can help spread awareness and get people interested in the project. Reconstructed SCALE-UP rooms seem particularly effective because these changes are difficult to undo and the financial investment makes reformers less likely to revert to traditional instruction.

We will treat these preliminary findings as hypotheses to test as we continue to collect data from more institutions.

\section{ACKNOWLEDGMENTS}

Thanks to all the faculty and administrators who participated in our survey and interviews. This project supported by NSF: \#1223405, 1223564, 1223405.

\section{REFERENCES}

1. R. Beichner,, J. Saul, D. Abbott, J. Morse, D. Deardorff, R. Allain \& J. Risley, Research-based reform of university physics, 1(1), 2-39 (2007).

2. E. Seymour. Sci. Ed., 86(1), 79-105 (2001).

3. Wieman, C. E., Perkins, K. K., \& Adams, W. K. AJP, 76(4), 393-399 (2008).

4. http://scaleup.ncsu.edu.

5. B. Ingram, M. Jesse, S. Fleagle, J. Florman, \& S. Van Horne, R. Carpenter (Ed.), Cases on higher education spaces: Innovation, collaboration, and technology (IGI Global, Hershey, PA, 2013), 165-185 (2013).

6. S. Van Horne, C. Murniati, J. Gaffney, J \& M. Jesse, J. of Learning Spaces, 1(2) (2012).

7. L. Benson, M. Orr, S. Biggers, W. Moss, M. Ohland \& S. Schiff, Inter. J. of Eng. Ed., 26(5), 1097-1110 (2010). 